\title{
Sustainability of crop production from polluted lands
}

\author{
P. C. Abhilash ${ }^{1}$ (D) Vishal Tripathi $^{1} \cdot$ Sheikh Adil Edrisi $^{1} \cdot$ Rama Kant Dubey $^{1} \cdot$ \\ Mansi Bakshi $^{1} \cdot$ Pradeep K. Dubey $^{1} \cdot$ H. B. Singh ${ }^{2} \cdot$ Stephen D. Ebbs $^{3}$ \\ ${ }^{1}$ Institute of Environment and Sustainable Development, Banaras Hindu University, Varanasi 221005, India \\ ${ }^{2}$ Institute of Agricultural Sciences, Banaras Hindu University, Varanasi 221005, India \\ ${ }^{3}$ Department of Plant Biology and Center for Ecology, Southern Illinois University, Carbondale, IL 62901-6509, USA
}

Received: 12 December 2015/Revised: 5 January 2016/Accepted: 6 January 2016/Published online: 14 February 2016

(c) Joint Center on Global Change and Earth System Science of the University of Maryland and Beijing Normal University and Springer-Verlag Berlin Heidelberg 2016

\begin{abstract}
Sustainable food production for a rapidly growing global population is a major challenge of this century. In order to meet the demand for food production, an additional land area of 2.7-4.9 Mha year ${ }^{-1}$ will be required for agriculture. However, one-third of arable lands are already contaminated; therefore, the use of polluted lands will have to feature highly in modern agriculture. The use of such lands comes, however, with additional challenges, and suitable agrotechnological interventions are essential for ensuring the safety and sustainability of relevant production system. There are also other issues to consider, such as cost-benefit analysis, the possible entry of pollutants into the phytoproducts, certification and marketing of such products, in order to achieve the large-scale exploitation of polluted lands. The present article addresses the sustainability challenges of crop production from polluted lands and briefly outlines the plausible strategies for using polluted lands for sustainable agricultural extensification.
\end{abstract}

Keywords Polluted lands - Crop production ·

Sustainability · Agricultural extensification · Bioeconomy · Phytoproducts

\section{Increasing crop production for a growing population: the need of the hour}

The population of the Earth is expected to reach $\sim 9.5$ billion people by the mid-twenty-first century (Godfray et al. 2010). Such an explosive rise in population will create the

P. C. Abhilash, Vishal Tripathi, Sheikh Adil Edrisi and Rama Kant Dubey have contributed equally to this work.

\section{P. C. Abhilash}

pcabhilash@hotmail.com; pca.iesd@bhu.ac.in demand for a $70 \%$ increase in food, feed and fiber production (Montanarella and Vargas 2012). Perhaps one of the greatest challenges is to increase the food production for a rapidly growing population in a sustainable manner (Foley et al. 2011). However, land is a limited resource and agricultural use of land will be in competition with land use for habitation, infrastructure and industry. Any modifications to the existing patterns of land use will affect the resilience of ecological and socioeconomic systems (Anderson 2010). Therefore, the dilemma is to increase the crop production without a significant increase in the use of arable land (Godfray and Garnett 2014). Accomplishing these goals will become increasingly difficult under changing climatic conditions and the resulting effects on crop growth, yield and disease susceptibility. The changing climate may also influence the nutritional quality of crops (Myers et al. 2014). There is a pressing need to develop suitable strategies for increasing global food production without any additional social, economic or ecological pressures (Rockström et al. 2009; Lambin and Meyfrodt 2011; Dubey et al. 2016).

One strategy to address these problems has been to leverage 'omic technologies' to engineer genetically modified (GM) crops with enhanced productivity, nutritional quality and/or stress tolerance. A significant drawback to this approach is the growing public resistance to GM crops (Ronald 2011), based principally on concerns about their perceived safety, the lack of scientific information on the long-term effects of GM crop consumption and the ethical considerations associated with genetic modification (Gilbert 2013). Intensifying traditional agricultural practices has been suggested as an immediate strategy for increasing the global food supply, but the excessive use of agrochemicals during the last few decades has already resulted in the severe 
pollution of biosphere (Abhilash et al. 2013a, b; Popp et al. 2013). Hence, $25 \%$ of global land resources are highly degraded and $\sim 44 \%$ are moderately degraded with the level of contamination is steadily increasing. Another strategy that could be used to meet global food demands would involve the safe and productive use of polluted lands to provide an additional avenue for agricultural extensification. There are a number of challenges associated with this approach, including the possible entry of pollutants into the phytoproducts. The present article examines the sustainability of crop production on polluted lands and provides potential strategies for converting polluted lands to an agricultural landscape to foster a bioeconomy (Jacobsen et al. 2013) for sustainable development.

\section{Crop production on polluted lands: an environmental point of view}

Land is a critical resource as it supports local food webs and contributes to global biogeochemical cycles. Land resources also provide agricultural production and support numerous other human needs and services. The terrestrial environment is also a primary sink for pollutants (Banwart 2011). The growing population exerts tremendous pressure on land for food, feed, fiber and biofuel production. It is estimated that an additional 2.7-4.9 Mha year $^{-1}$ will be required to meet the food demand of growing populations (Lambin and Meyfrodt 2011). The agricultural extensification of new landscapes at the cost of existing forests, wetlands and grasslands is not a sustainable option as it accelerates the biodiversity loss and other environmental issues (Garnett et al. 2013). However, by adopting prudent scientific and technological interventions, polluted lands could be utilized safely for agricultural production (Lambin and Meyfrodt 2011). Polluted lands are generally perceived as a potential threat to human health and food safety, but the demand for arable lands will inevitably require that these lands be considered as an untapped resource for environmental and agricultural sustainability (Abhilash et al. 2013a, b; Weyens et al. 2009). Using polluted lands for agriculture will not only address the increased food demand of growing populations but will also restore those degraded lands to productive use rather leaving them dormant and unused. There is also the potential to couple agricultural production on polluted lands with the cultivation of biomass and biofuel crops to meet growing energy demand (Weyens et al. 2009) and with biofortification efforts to improve the nutrient content of agricultural products (Zhao and McGrath 2009). Nevertheless, there are several ecotoxicological, economic and social considerations associated with crop production on polluted lands that must be thoroughly addressed (Tripathi et al. 2014a). The following sections provide (1) a state of the art of crop productions from polluted lands and (2) strategies for simultaneously minimizing the potential risk to human receptors while converting crop production on polluted lands into a sustainable enterprise.

\section{Polluted lands for edible crop production and biofortification}

A selected list of crop plants being tested under field and controlled conditions is provided in Table 1. The uptake and accumulation of pollutants in crops vary with species or cultivars, the type of pollutants and level of contamination (Khan et al. 2010; Ismail et al. 2014). For instance, a field trial on a moderately Cd-contaminated (0.69-0.96 $\mathrm{mg} \mathrm{kg}^{-1}$ ) site in China based on a rotation system of rape (Brassica napus L.) seed to rice (Oryza sativa L.) restricted the phytoaccumulation of $\mathrm{Cd}$ in rice. The rape seed cultivar Zhucang Huzai accumulated a high $\mathrm{Cd}$ concentration $\left(>0.2 \mathrm{mg} \mathrm{kg}^{-1}\right)$, whereas the $\mathrm{Cd}$ concentration in cultivar Chuanyou II-93 was well below the limit as given in Table 1. Similarly, Cd concentrations of the brown rice were below the permissible limits (Yu et al. 2014). The concentrations of $\mathrm{As}, \mathrm{Cu}, \mathrm{Co}, \mathrm{Pb}$ and $\mathrm{Zn}$ in cassava (Manihot esculenta Crantz) growing on the contaminated soils of the Zambian copper belt were reported by Kríbek et al. (2014). Interestingly, the level of $\mathrm{Cu}$ in leaves and tubers of cassava grown in strongly contaminated areas do not exceed the daily maximum tolerance limit for dietary intake $\left(0.5 \mathrm{mg} \mathrm{kg}^{-1}\right.$ body weight). However, the highest tolerable weekly ingestion of $\mathrm{Pb}$ and $\mathrm{As}$ exceeded the relevant dietary limits in the vicinity of smelters.

Warren et al. (2003) conducted a detailed field trial to assess the uptake of As by beet (Beta vulgaris L.), calabrese vegetables like cauliflower (Brassica oleracea var botrytus), lettuce (Lactuca sativa L.), potato (Solanum tuberosum L.), radish (Raphanus sativus L) and spinach (Spinacia oleracea L.) growing on As-contaminated soil (748 $\left.\mathrm{mg} \mathrm{kg}^{-1}\right)$ near an As smelter in Cornwall, UK. This soil had been amended with ferrous sulfate and lime in an effort to remediate the soils through precipitation of Fe oxides in the contaminated soil. In all field trials except for spinach, ferrous sulfate addition significantly reduced the As translocation to edible parts. Moreover, the application of $0.2 \% \mathrm{Fe}$ oxides to soil surface $(0-10 \mathrm{~cm})$ reduced the As uptake by $22 \%$, whereas the application of $0.5 \% \mathrm{Fe}$ oxides reduced the As availability by $32 \%$ (Warren et al. 2003). Madejón et al. (2011) employed traditional agricultural practices in a heavily contaminated soil in Southern Spain to limit the accumulation of $\mathrm{As}, \mathrm{Cu}, \mathrm{Pb}$ and $\mathrm{Zn}$ in onion (Allium cepa $\mathrm{L}$.), lettuce, chard (B. vulgaris L.), potato and lemon (Citrus limon L. Burm.f.). The metal concentration was low in crops when the 
Table 1 An indicative list of trials conducted for crop production from contaminated lands and the level of accumulation in edible parts

\begin{tabular}{|c|c|c|c|c|c|}
\hline Crops types & Pollutant level $\left(\mathrm{mg} \mathrm{kg}^{-1}\right)$ & Plant parts & $\begin{array}{l}\text { Type of } \\
\text { study }\end{array}$ & $\begin{array}{l}\text { FAO/WHO } \\
\text { standards } \\
\left(\mathrm{mg} \mathrm{kg}^{-1}\right)\end{array}$ & Refs. \\
\hline \multicolumn{6}{|l|}{ Cereals } \\
\hline $\begin{array}{l}\text { Barley (Hordeum } \\
\text { vulgare L.) }\end{array}$ & $\operatorname{Se}(0.17)$ & Grains & Field & Not available & Ilbas et al. (2012) \\
\hline Maize (Zea mays L.) & $\begin{array}{l}\mathrm{Cd}(0.07), \mathrm{Pb}(0.10), \mathrm{Zn} \\
\quad(0.73)\end{array}$ & Grains & Field & $\begin{array}{l}\mathrm{Cd}(0.2), \mathrm{Pb}(0.3) \\
\quad \mathrm{Zn}(100)\end{array}$ & Meers et al. (2010) \\
\hline Rice (Oryza sativa L.) & $\mathrm{Zn}(22.8-23.8), \mathrm{Cd}(0.1)$ & Grains & Greenhouse & $\mathrm{Zn}(100), \mathrm{Cd}(0.2)$ & $\begin{array}{l}\text { Weyens et al. (2009), } \\
\text { Yu et al. (2014) }\end{array}$ \\
\hline $\begin{array}{l}\text { Sorghum (Sorghum } \\
\text { biocolor L.) }\end{array}$ & $\mathrm{Cu}$ (96.2), Zn (80.9) & Leaves, roots & Field & $\begin{array}{l}\mathrm{Cu}(500), \mathrm{Zn} \\
\quad(100)\end{array}$ & Zhuang et al. (2009) \\
\hline \multicolumn{6}{|l|}{ Oil seeds } \\
\hline $\begin{array}{l}\text { Rapeseed (Brassica } \\
\text { napus L.) }\end{array}$ & $\mathrm{Cd}(0.2)$ & Whole plant & Field & $\mathrm{Cd}(0.2)$ & Yu et al. (2014) \\
\hline $\begin{array}{l}\text { Indian mustard } \\
\quad(\text { Brassica juncea } \text { L.) }\end{array}$ & $\mathrm{Ni}(38)$ & Whole plant & Field & $\mathrm{Ni}(67)$ & $\begin{array}{l}\text { Bauddh and Singh } \\
\text { (2012) }\end{array}$ \\
\hline \multicolumn{6}{|l|}{ Vegetables/fruits } \\
\hline $\begin{array}{l}\text { Beetroot (Beta vulgaris } \\
\text { L.) }\end{array}$ & As $(<0.08)$ & Tubers & Field & As $(0.1)$ & Warren et al. (2003) \\
\hline $\begin{array}{l}\text { Bitter gourd } \\
\quad \text { (Momordica } \\
\text { charantia } \mathrm{L} .)\end{array}$ & $\mathrm{Pb}(0.3)$ & Fruit & Field & $\mathrm{Pb}(0.3)$ & Ismail et al. (2014) \\
\hline $\begin{array}{l}\text { Carrot (Daucus carota } \\
\text { L.) }\end{array}$ & $\mathrm{Ni}(0.73)$ & Roots & Pot & Ni (67) & $\begin{array}{l}\text { Stasinos and } \\
\text { Zabetakis (2013) }\end{array}$ \\
\hline $\begin{array}{l}\text { Cassava (Manihot } \\
\text { esculenta Crantz) }\end{array}$ & $\begin{array}{l}\text { As }(0.1), \text { Co }(<0.5), \mathrm{Cu} \\
\quad(1.7), \mathrm{Zn}(11)\end{array}$ & Peeled tubers & Field & $\begin{array}{l}\text { As }(0.1), \mathrm{Co}(50), \\
\mathrm{Cu}(500), \mathrm{Pb} \\
(0.3), \mathrm{Zn}(100)\end{array}$ & Kř́ibek et al. (2014) \\
\hline $\begin{array}{l}\text { Cauliflower (Brassica } \\
\text { oleracea } \text { var. botrytis) }\end{array}$ & $\mathrm{Cu}(1.86)$ & Shoots & Field & $\mathrm{Cu}(500)$ & Ismail et al. (2014) \\
\hline $\begin{array}{l}\text { Lettuce (Lactuca sativa } \\
\text { L.) }\end{array}$ & As $(0.08)$ & Shoots & Field & As $(0.1)$ & Warren et al. (2003) \\
\hline Onion (Allium cepa L.) & Ni (1.78) & Shoots & Pot & $\mathrm{Ni}(67)$ & $\begin{array}{l}\text { Stasinos and } \\
\text { Zabetakis (2013) }\end{array}$ \\
\hline $\begin{array}{l}\text { Pineapple (Ananas } \\
\text { comosus (L.) Merr.) }\end{array}$ & $\begin{array}{l}\text { Marginal or degraded } \\
\text { lands (NA) }\end{array}$ & Fruits & Field & NA & Borland et al. (2009) \\
\hline $\begin{array}{l}\text { Potato (Solanum } \\
\text { tuberosum L.) }\end{array}$ & As (0.08), Ni (0.32) & Tubers & $\begin{array}{l}\text { Field and } \\
\text { pot }\end{array}$ & As (0.1), Ni (67) & $\begin{array}{l}\text { Warren et al. (2003), } \\
\text { Stasinos and } \\
\text { Zabetakis (2013) }\end{array}$ \\
\hline $\begin{array}{l}\text { Radish (Raphanus } \\
\text { sativus L.) }\end{array}$ & $\mathrm{Zn}(47.94)$ & Pods & Field & $\mathrm{Zn}(100)$ & Ismail et al. (2014) \\
\hline $\begin{array}{l}\text { Spinach (Spinacia } \\
\text { oleracea L.) }\end{array}$ & $\begin{array}{l}\mathrm{Cd}(0.05), \mathrm{Co}(0.36), \mathrm{Ni} \\
(2.03), \mathrm{Fe}(202.66), \mathrm{Mn} \\
(6.23), \mathrm{As}(<0.08)\end{array}$ & Shoots & Field & $\begin{array}{l}\text { Cd (0.2), Co (50), } \\
\text { Ni (67), Fe } \\
(425), \mathrm{Mn}(73), \\
\text { As }(0.1)\end{array}$ & $\begin{array}{l}\text { Ismail et al. (2014), } \\
\text { Warren et al. (2003) }\end{array}$ \\
\hline \multicolumn{6}{|l|}{ Ornamentals } \\
\hline $\begin{array}{l}\text { Chrysanthemum } \\
\text { (Chrysanthemum } \\
\text { indicum L. and C. } \\
\text { maximum (DC.) } \\
\text { Parsa) }\end{array}$ & $\begin{array}{l}\mathrm{Cd}(7.4), \mathrm{Cu}(7.3-8.5), \mathrm{Zn} \\
\quad(\simeq 130), \mathrm{Ni}(\simeq 214), \mathrm{Pb} \\
\quad(\simeq 110)\end{array}$ & $\begin{array}{l}\mathrm{Cd} \text { (shoots), } \mathrm{Cu} \text { (flowers), } \\
\mathrm{Zn} \text { (whole plant), Ni } \\
\text { (whole plant), } \mathrm{Pb} \text { (whole } \\
\text { plant) }\end{array}$ & $\begin{array}{l}\text { Field and } \\
\text { pot }\end{array}$ & NA & $\begin{array}{l}\text { Lal et al. (2008), } \\
\text { González-Chávez } \\
\text { and Carrillo- } \\
\text { González (2013) }\end{array}$ \\
\hline $\begin{array}{l}\text { Cock's comb (Celosia } \\
\text { cristata L.) }\end{array}$ & $\begin{array}{l}\mathrm{Cr}(\simeq 159.5), \mathrm{Mn}(\simeq 145) \\
\mathrm{Fe}(\simeq 8000), \mathrm{Cu} \\
\quad(\simeq 79.5), \mathrm{Zn}(\simeq 1010) \\
\mathrm{Pb}(\simeq 159)\end{array}$ & Whole plant & Field & NA & $\begin{array}{l}\text { Chatterjee and Singh } \\
\text { (2012) }\end{array}$ \\
\hline
\end{tabular}


Table 1 continued

\begin{tabular}{|c|c|c|c|c|c|}
\hline Crops types & Pollutant level $\left(\mathrm{mg} \mathrm{kg}^{-1}\right)$ & Plant parts & $\begin{array}{l}\text { Type of } \\
\text { study }\end{array}$ & $\begin{array}{l}\mathrm{FAO} / \mathrm{WHO} \\
\text { standards } \\
\left(\mathrm{mg} \mathrm{kg}^{-1}\right)\end{array}$ & Refs. \\
\hline $\begin{array}{l}\text { Gladiolus (Gladiolus } \\
\text { grandiflorus } \\
\text { Andrews) }\end{array}$ & $\mathrm{Cd}(8.0)$ & Shoots & Field & NA & $\begin{array}{l}\text { Lal et al. } \\
\text { (2008) }\end{array}$ \\
\hline $\begin{array}{l}\text { Marigold (Tagetes } \\
\text { erecta } \mathrm{L} .)\end{array}$ & $\mathrm{Cd}(7.0), \mathrm{Cu}(\simeq 310)$ & $\begin{array}{l}\mathrm{Cd} \text { (Shoots), } \mathrm{Cu} \text { (whole } \\
\text { plant) }\end{array}$ & Field & NA & $\begin{array}{l}\text { Lal et al. } \\
\text { (2008), } \\
\text { Castillo et al. } \\
\text { (2011) }\end{array}$ \\
\hline $\begin{array}{l}\text { Marigold (Tagetes } \\
\text { patula } \mathrm{L} .)\end{array}$ & $\mathrm{Cr}$ (15.8), $\mathrm{Cu}(22), \mathrm{Zn}(163), \mathrm{Pb}(43)$ & $\begin{array}{l}\mathrm{Cr} \text { (roots), } \mathrm{Cu} \text { (flower), } \mathrm{Zn} \\
\quad \text { (stem), } \mathrm{Pb} \text { (roots) }\end{array}$ & Field & NA & $\begin{array}{r}\text { Chatterjee and } \\
\text { Singh (2012) }\end{array}$ \\
\hline $\begin{array}{l}\text { Sunflower (Helianthus } \\
\text { annuus L.) }\end{array}$ & $\begin{array}{l}\mathrm{Cr}(56), \mathrm{Mn}(71), \mathrm{Cu}(48), \mathrm{Zn}(469), \mathrm{Pb} \\
\quad(47.9)\end{array}$ & Roots & Field & NA & $\begin{array}{r}\text { Chatterjee and } \\
\text { Singh (2012) }\end{array}$ \\
\hline \multicolumn{6}{|l|}{ Biomass/bioenergy } \\
\hline $\begin{array}{r}\text { Castor (Ricinus } \\
\text { communis L.) }\end{array}$ & $\begin{array}{l}\mathrm{Cd}(0.37,0.43), \mathrm{DDT}(1.22,2.27), \mathrm{Fe} \\
(\simeq 280), \mathrm{Zn}(\simeq 65), \mathrm{Cr}(\simeq 50), \mathrm{Pb} \\
(\simeq 30), \mathrm{Ni}(\simeq 12), \text { and As }(\simeq 0.045)\end{array}$ & $\begin{array}{l}\text { Cd (leaf, stem), DDT } \\
\text { (leaf, stem), Fe, Zn, Cr, } \\
\text { Pb, Ni, As (whole plant) }\end{array}$ & Field & NA & $\begin{array}{l}\text { Huang et al. } \\
\text { (2011), } \\
\text { Irshad et al. } \\
\text { (2014) }\end{array}$ \\
\hline $\begin{array}{l}\text { Common reed } \\
\text { (Phragmites australis } \\
\text { (Cav.) Steud.) }\end{array}$ & $\begin{array}{l}\mathrm{Cd}(<0.2), \mathrm{Cr}(0.23), \mathrm{Cu}(3.72), \mathrm{Mn} \\
\quad(28.65), \mathrm{Pb}(5.27), \mathrm{Zn}(16.52)\end{array}$ & Shoots & Field & NA & $\begin{array}{l}\text { Bonanno et al. } \\
\text { (2013) }\end{array}$ \\
\hline Maize (Zea mays L.) & Cd (0.89), Zn (211) & Whole plant & Field & NA & $\begin{array}{l}\text { Ruttens et al. } \\
\text { (2011) }\end{array}$ \\
\hline $\begin{array}{l}\text { Mesquite (Prosopis } \\
\text { juliflora (Sw.) DC.) }\end{array}$ & $\begin{array}{l}\text { As }(0.14), \mathrm{Cd}(0.17), \mathrm{Cr}(0.02), \mathrm{Cu} \\
\quad(11.8), \mathrm{Mn}(117), \mathrm{Pb}(2.88), \mathrm{Zn}(73.4)\end{array}$ & Whole plant & Field & NA & $\begin{array}{l}\text { Solís- } \\
\text { Domínguez } \\
\text { et al. (2011) }\end{array}$ \\
\hline $\begin{array}{l}\text { Physic Nut (Jatropha } \\
\text { curcas L.) }\end{array}$ & As (0.06), $\mathrm{Cr}$ (1.26), Mn, $\mathrm{Zn}(6.5)$ & As, Cr, Zn (stem) & Greenhouse & NA & $\begin{array}{l}\text { Juwarkar et al. } \\
\text { (2008) }\end{array}$ \\
\hline $\begin{array}{l}\text { Pongam (Pongamia } \\
\text { glabra Vent.) }\end{array}$ & $\begin{array}{l}\mathrm{Cr}(106), \mathrm{Mn}(71.8), \mathrm{Fe}(908), \mathrm{Co}(19.1) \\
\quad \mathrm{Ni}(39.4), \mathrm{Cu}(37), \mathrm{Zn}(469), \mathrm{Pb} \\
(25.26)\end{array}$ & Leaves & Field & NA & $\begin{array}{l}\text { Ravikumar } \\
\text { et al. (2013) }\end{array}$ \\
\hline $\begin{array}{l}\text { Prickly acacia (Acacia } \\
\text { nilotica Delile) }\end{array}$ & $\begin{array}{l}\mathrm{Fe}(\simeq 240), \mathrm{Zn}(\simeq 175), \mathrm{Cr}(\simeq 150), \mathrm{Pb} \\
\quad(\simeq 105), \mathrm{Ni}(\simeq 20), \mathrm{Cd}(\simeq 9), \mathrm{As} \\
\quad(\simeq 0.045)\end{array}$ & Whole plant & Field & NA & $\begin{array}{l}\text { Irshad et al. } \\
\text { (2014) }\end{array}$ \\
\hline $\begin{array}{l}\text { Rush wheatgrass } \\
\text { (Elymus elongatus } \\
\text { subsp. ponticus cv. } \\
\text { Szarvasi-1) }\end{array}$ & $\mathrm{Zn}(300), \mathrm{Pb}(1.35)$ & $\mathrm{Zn}$ (shoot), $\mathrm{Pb}$ (root) & Pot & NA & $\begin{array}{l}\text { Sipos et al. } \\
\text { (2013) }\end{array}$ \\
\hline $\begin{array}{l}\text { Ryegrass (Lolium } \\
\text { perenne L.) }\end{array}$ & $\begin{array}{l}\mathrm{Zn}(\simeq 210), \text { As }(\simeq 1.8), \mathrm{Cd}(\simeq 1.2), \mathrm{Pb} \\
\quad(\simeq 30)\end{array}$ & Roots and shoots & Pot & NA & $\begin{array}{l}\text { Guo et al. } \\
\text { (2014) }\end{array}$ \\
\hline $\begin{array}{l}\text { Sorghum (Sorghum } \\
\text { biocolor L.) }\end{array}$ & $\begin{array}{l}\mathrm{Pb}(2.31), \mathrm{Zn}(80.9), \mathrm{Cd}(96.2), \mathrm{Cu} \\
\quad(96.2)\end{array}$ & $\begin{array}{l}\mathrm{Pb}, \mathrm{Zn} \text { (leaves), } \mathrm{Cd} \\
\text { (roots), } \mathrm{Cu} \text { (shoots) }\end{array}$ & Field & NA & $\begin{array}{l}\text { Zhuang et al. } \\
\text { (2009) }\end{array}$ \\
\hline $\begin{array}{l}\text { Soybean (Glycine max } \\
\text { (L.) Merr.) }\end{array}$ & $\mathrm{Cd}(6.2,11.5)$ & Shoots, roots & Greenhouse & NA & $\begin{array}{l}\text { Murakami } \\
\text { et al. (2007) }\end{array}$ \\
\hline $\begin{array}{l}\text { Yellow lupin (Lupinus } \\
\text { luteus L.) }\end{array}$ & $\begin{array}{l}\text { As }(<1.5), \mathrm{Cu}(21.5), \mathrm{Cd}(1.6), \mathrm{Pb}(3.5) \\
\mathrm{Zn}(472)\end{array}$ & Shoots & Field & NA & $\begin{array}{l}\text { Dary et al. } \\
\quad(2010)\end{array}$ \\
\hline
\end{tabular}

soils were limed annually and with animal manure application (Madejón et al. 2011). In all cases except for $\mathrm{Zn}$ and $\mathrm{Pb}$, the accumulation of metals was below the regulatory limits. The heavy metal concentrations in vegetables growing on a contaminated fluvial deposit of Gilgit, Pakistan (Khan et al. 2010), were 0.24-2.1 $\mathrm{mg} \mathrm{Cd} \mathrm{kg}^{-1}, 15-44 \mathrm{mg} \mathrm{Pb} \mathrm{kg}^{-1}$ and 40-247 $\mathrm{mg} \mathrm{Zn} \mathrm{kg}^{-1}$, values generally above the regulatory limit.
Biofortification of edible plants is another avenue that could be achieved through cropping on soil polluted with contaminants that are essential micronutrients (e.g., Fe, Zn, $\mathrm{Cu} \mathrm{Mg}$ and Se) (Zhu et al. 2009; Vamerali et al. 2014). Selenium is an important dietary micronutrient required for animals and beneficial for plants (Madejón et al. 2011). Selenomethionine (SeMet) is the major chemical species of Se in several grains like barley (Hordeum vulgare L.), wheat 
(Triticum aestivum L.) and rye (Secale cereale L.) contributing to about 60-80\% of the total Se content (Stadlober et al. 2001). X-ray absorption near edge spectroscopic analysis of a rice sample obtained from a Se-contaminated region of Enshi district in south-central China revealed that $\mathrm{Se}$ in rice can be found predominantly as selenomethylcysteine (SeMeSeCys) in addition to SeMet (Williams et al. 2009). Selenomethylcysteine is believed to have anti-carcinogenic properties. Moreover, both SeMeSeCys and SeMet provide supplementary health benefits over inorganic Se (Rayman 2008; Rayman et al. 2008). Normally, the Se levels in the rice were reported to have 33-50\% (Beilstein et al. 1991). Since soils contaminated with Se are reported worldwide, these soils could be used for cropping Se-accumulating crops for biofortification. Selenium can also lower the uptake of $\mathrm{Pb}$ in rice, thereby lowering the accumulation of $\mathrm{Pb}$ in grains ( $\mathrm{Yu}$ et al. 2014). Hence, cropping on Se-contaminated soils might also reduce the uptake of other pollutants as well. Linseed (Linum usitatissimum L.) growing on contaminated soils with elevated concentrations of $\mathrm{Fe}, \mathrm{Cu}$ and $\mathrm{Zn}$ displayed enhanced height and number of capsules per plant (Rastogi et al. 2014). Since these metals are also essential micronutrients, cultivating linseed on metal-contaminated soil could enhance nutrient density in seeds. Vamerali et al. (2014) studied the biofortification and remediation potential of radish and maize (Zea mays L.) cultivated in a pyrite waste dump at Torviscosa (Udine), Italy. Although the accumulation of various heavy metals in maize grains (in $\mathrm{mg} \mathrm{kg}^{-1}$ ) such as $\mathrm{Cd}(<0.001)$, $\mathrm{Co}(<0.002), \mathrm{Cr}$ (0.12), $\mathrm{Cu}$ (3.28), Mn (6.17), Ni (0.41), Pb $(<0.001)$ and $\mathrm{Zn}(40.2)$ was found to be lower, the concentrations of $\mathrm{Cd}$ (2.34) and $\mathrm{Pb}$ (4.20) in radish were higher than the permissible limit set by the European Union. There are additional studies reporting that the accumulation of toxic metals in edible parts of plants growing on polluted soils falls within the regulatory limits. For example, the $\mathrm{Cd}$, $\mathrm{Pb}$ and $\mathrm{Zn}$ accumulation in maize grain (Meers et al. 2010), As accumulation in beet root and lettuce (Warren et al. 2003) and the Ni concentration in carrot and onion (Stasinos and Zabetakis 2013) were below the limit. The above cases demonstrate that crop production on contaminated lands is being widely investigated (Figs. 1,2) and that cultivation of crops on polluted soils does not immediately result in edible tissues with pollutant concentrations that exceed regulatory limits. Such results offer proof of concept that the utilization of such lands for agriculture is possible.

\section{Polluted lands for floriculture}

The cultivation of edible plants on polluted lands would even if successful be under continual scrutiny because of the potential for accumulation of pollutants in edible tissues (Dziubanek et al. 2015). Another approach could be to restrict cultivation to non-food crops, such as those used for floriculture, horticulture, biomass, biofuels or production of commercially important chemicals (Lal et al. 2008; Jamil et al. 2009). In this context, cultivating ornamental plants on contaminated lands is a logical choice as it provides economic benefits, aesthetic value and possibly also ecological services during propagation to birds, honeybees, butterflies and other species (Lal et al. 2008; Ling-Zhi et al. 2011). There is likely to be increased demand of flowers and other ornamental plants in the future as the standard of living improves in many parts of the world (Wang and Zhou 2005). This creates a potential future scenario where floriculture crops will also compete with food crops for arable lands. Shifting floriculture production to contaminated lands could represent a viable strategy (Table 1). Species like marigold (Tagetes sp.) (Lal et al. 2008; Chatterjee and Singh 2012), scarlet sage (Salvia splendens L.), sweet hibiscus (Abelmoschus manihot L.) (Wang and Zhou 2005), chrysanthemum (Chrysanthemum indicum L.) (Lal et al. 2008; González-Chávez and Carrillo-González 2013), gladiolus (Gladiolus grandiflorus Andrews) (Lal et al. 2008), sunflower (Helianthus annuus L.) (Chatterjee and Singh 2012) and cock's comb (Celocia cristata L.) are already being tested in fields (Lal et al. 2008; Ling-Zhi et al. 2011; Wang and Zhou 2005). Native ornamental species growing near to the polluted sites can also be used for floriculture as they show plasticity and ability to grow in polluted soils (e.g., metal excluders) (de Abreu et al. 2012). For example, species of Cistus thrive in metalcontaminated soils. Cistus populifolius and C. salviifolius and their hybrid Cistus $\times$ hybridus showed tolerance to hazardous metals and are non-accumulators of $\mathrm{As}, \mathrm{Cu}, \mathrm{Pb}$, Fe and Sb (de Abreu et al. 2012). Similarly, Erica australis, E. andevalensis, Lavandula luisierra, Daphne gnidium, Rumex induratus, Ulex eriocladus, Juncus and Genista hirsutus showed metal tolerance when grown on sites contaminated with multiple metals (Anawar et al. 2011). Continued research such as this is essential to maximize the profitability and ensure the safety of ornamentals produced on polluted lands.

\section{Polluted lands for biomass and biofuel production}

Fuel versus food production is another global debate as it involves competition for available land. Shifting biomass and biofuel production to polluted land could be a promising approach to overcome this competition (Cai et al. 2011; Edrisi and Abhilash 2016). Moreover, the production of biofuel crops from polluted lands may also 


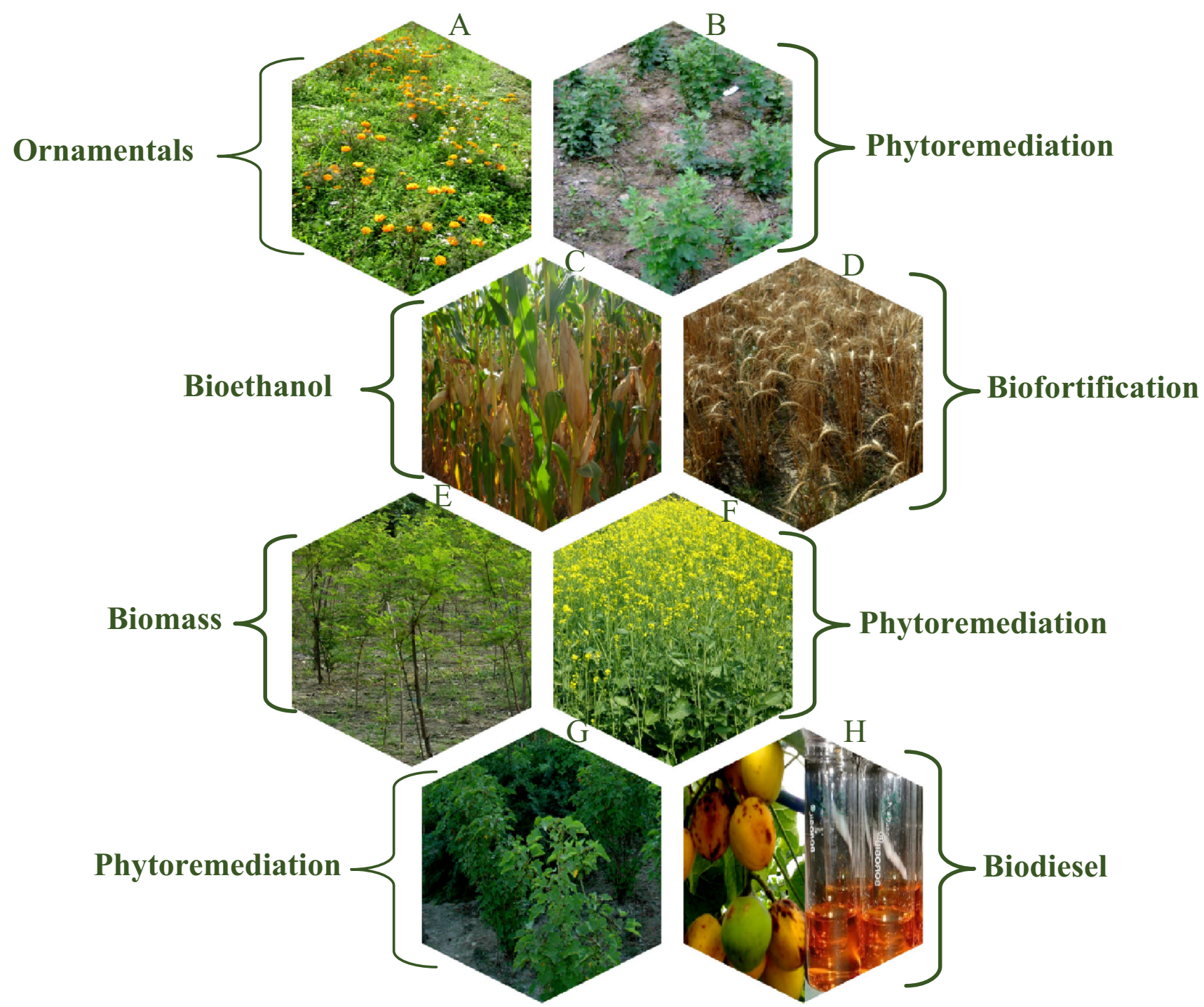

Fig. 1 Hexagons represent multipurpose species for bioremediation and economic returns from polluted soil. A Marigold (Lal et al. 2008) and $B$ Chrysanthemum (González-Chávez and Carrillo-González 2013) are candidate species for floriculture. $C$ Maize can be used for bioethanol production (Meers et al. 2010), $D$ Wheat can be used for biofortification, $E$ White leadtree can be cultivated for biomass production in organic and inorganic pollutants contaminated soil (Abhilash et al. 2013a, b), $F$ Indian mustard is a well-known accumulator for toxic metals, $G$ Jatropha growing in flyash dumps (photo credit: Sara Jamil) and $H$ Biofuel extracted from Jatropha seeds (Edrisi et al. 2015) reduce $\mathrm{CO}_{2}$ emissions and pollution (Delucchi 2006). There are several candidate species that could be considered, such as physic nut (Jatropha curcas L.), white leadtree (Leucena leucocephala (Lam.) de Wit), castor bean (Ricinus cummunis L.), Indian beech (Pongamia pinnata L. Panigrahi), poplar (Populus sp.), switchgrass (Panicum virgatum L.) and Miscanthus giganteus that are known to have the potential to grow in polluted and degraded land (Cai et al. 2011; Olivares et al. 2013; Tang et al. 2010). Physic nut is usually well adapted to arid to semiarid climate and can grow in marginal lands, fly ash dumps and pesticide-contaminated soils (Edrisi et al.
2015; Abhilash et al. 2013a, b; Edrisi and Abhilash 2016). Similarly, leadtree and castor bean have the potential to grow and remediate soils contaminated with either organic or inorganic pollutants or a mixture of both the pollutants. These species showed a capacity to accumulate contaminants like $\mathrm{Cd} \quad\left(0.43 \mathrm{mg} \mathrm{kg}^{-1}\right)$ and DDTs (2.27 mg kg${ }^{-1}$ ) (Huang et al. 2011). Poplar is another promising species that can grow in many multi-contaminant sites (e.g., TCE and heavy metals) (Weyens et al. 2013). The hybrid M. giganteus has potential to grow in $\mathrm{Cd}-, \mathrm{Zn}-$ and Pb-contaminated (Pavel et al. 2014) lands and also has a significant potential for bioethanol 


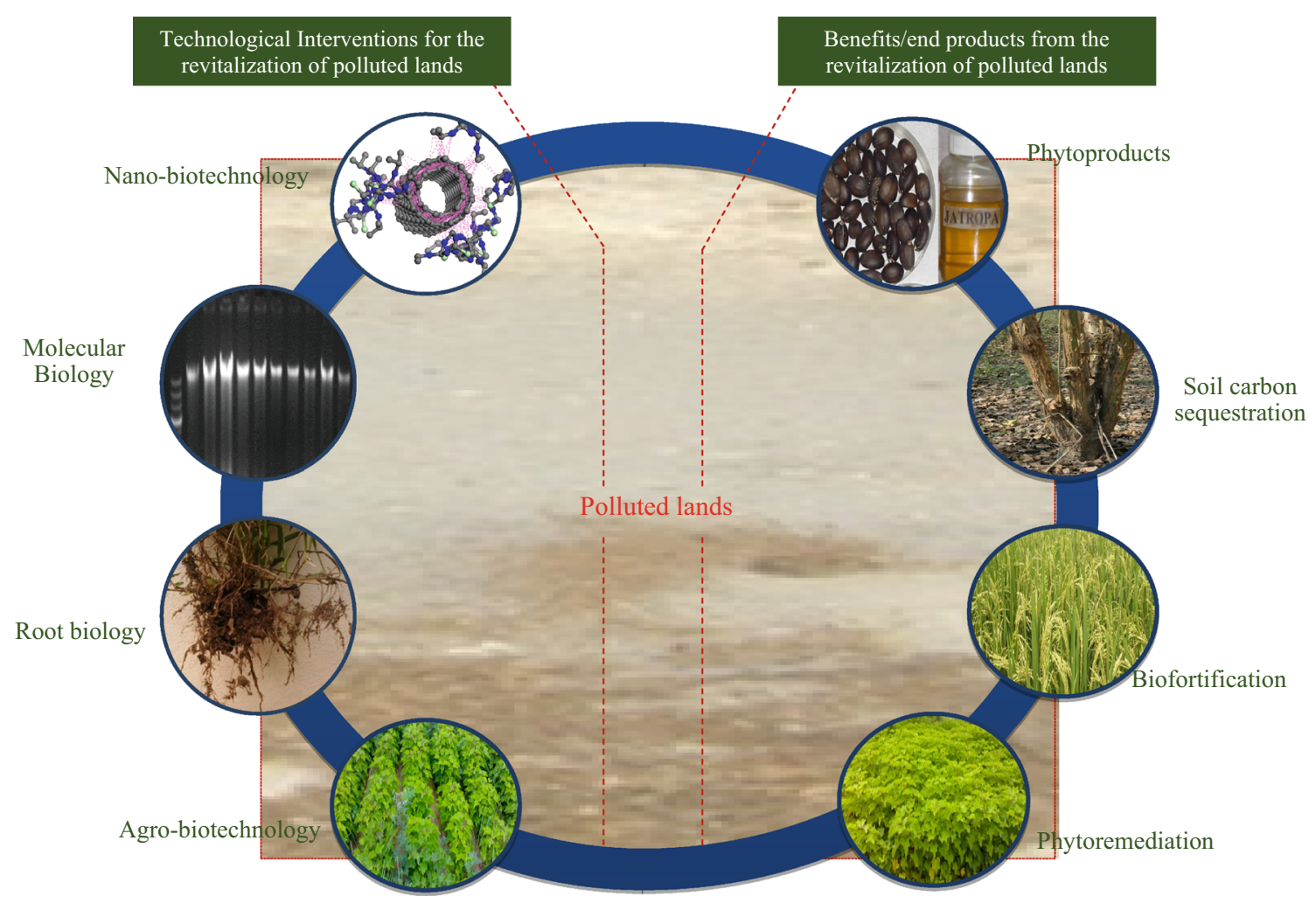

Fig. 2 Strategies for enhancing the sustainability of crop production from polluted lands. The application of agrobiotechnology, root biology, molecular biology and nano-biotechnology can be used for crop production from such lands (Germaine et al. 2009; Hur et al. 2011; Houben et al. 2013; El-Temsah 2013; Meister et al. 2014; Abhilash and Dubey 2015)

\section{Strategies for minimizing the uptake and accumulation of toxic pollutants in edible parts}

Perhaps the most significant concern is that the cultivation of edible plants on contaminated lands will lead to the accumulation of pollutants in edible parts and in excess of the regulatory limits (Ye-Tao et al. 2012). Preventing potential health risks is one of the major challenges for the large-scale exploitation of polluted lands for crop production. Although most of the plants have the inherent capacity to detoxify the pollutants, the complete detoxification or elimination of the accumulated pollutant does not occur (Abhilash et al. 2009). Hence, plants can in some situations biomagnify the pollutant in the food chain (Köhler and Triebskorn 2013). Additionally, the presence of toxic of pollutants in the contaminated lands may hamper the establishment, growth and yield of the crop plants. These detrimental effects may be accentuated if the polluted soil lacks the necessary nutrients or beneficial microorganisms necessary for adequate growth and development (Abhilash et al. 2013a, b). These conditions create the need for sitespecific agronomic practices and agrotechnological 
interventions to enhance the plant growth under adverse conditions while also restricting the transfer of toxic pollutants to the phytoproducts (Dubey et al. 2014; Tripathi et al. 2014a, b, 2015a, b). Such strategies must be targeted toward (1) selecting and breeding for low-accumulating cultivars (phytoexcluders) for polluted lands, (2) reducing the bioavailability of pollutants in the soil and (3) restricting the uptake and translocation of pollutants to edible parts (YeTao et al. 2012). The ensuing sections briefly highlight various strategies that can be employed to achieve these endpoints (Fig. 2).

Previous studies reported that the accumulation of pollutants in plants depends to a significant degree upon the plant species, cultivar and species-specific traits. For example; Ye-Tao et al. (2012) extensively reviewed the differences in the uptake of heavy metals among different cultivars of rice, maize, wheat and soybean (Glycine max L). A comprehensive screening of suitable species for cultivars with reduced accumulation is an important step in the cropping of polluted lands. Once suitable species/ cultivars are identified, site-specific and crop-specific agronomic practices can be optimized to enhance the plant-microbe interactions, increase nutrient and fertilizer efficiency, and reduce the toxicity and phytoavailability of the pollutants (Gilbert 2013; Abhilash et al. 2012). Chemical immobilization, for example, is a cost-effective way to reduce the heavy metal uptake in plants through the addition of soil amendments such as lime-, phosphateand silicon-based materials, or adsorption agents (e.g., zeolites, iron oxides, manganese oxides and clay minerals) (Ye-Tao et al. 2012; Kashem et al. 2010). Similarly, organic amendments such as peat, biochar, manure, sludge, agricultural residues, compost or vermicompost are potentially favorable as they reduce the availability of the pollutant to plants and also provide nutrients to plants. These amendments may also support microbial consortia capable of degrading organic pollutants. For example, Houben et al. (2013) reported that the addition of $10 \%$ biochar to heavy metal-contaminated soil enhanced the production of rape seed while reducing the heavy metal concentration of $\mathrm{Cd}, \mathrm{Zn}$ and $\mathrm{Pb}$ by 71,87 and $92 \%$, respectively (Houben et al. 2013). Similarly, amending polluted soil with activated carbon, charcoal or compost reduced the dissolved PAH concentrations as well their uptake and accumulation in radish (Marchal et al. 2014). Humic acid has been recommended as an amendment to facilitate biofortification (Vamerali et al. 2014), whereas chelating agents were reported to be helpful in reducing the toxicity of metals. Crop rotation, soil tillage, intercropping, capping, drip irrigation, inoculation of plant growth-promoting rhizobacteria (PGPR) and endophytes and application of microbial enzymes can also enhance the bioremediation of soil contaminants and improve plant growth with reduced accumulation of pollutants in edible parts (Karigar and Rao 2011; Rao et al. 2010; Tripathi et al. 2013; Segura and Ramos 2013; Vishnoi and Srivastava 2008; Álvareza et al. 2012; Wang et al. 2004). Such agronomic practices can enhance the plant-microbe interactions necessary for sustainable agriculture on polluted lands.

Rhizospheric engineering is another approach to modify the rhizospheric environment to improve the fertility of contaminated lands while also degrading pollutants in the root zone (Kumar 2013; Abhilash and Dubey 2015). Such manipulations can change the soil microbial community structure (Hur et al. 2011), AMF colonization (Gao et al. 2012) and endophytic microbial association (Germaine et al. 2009). Furthermore, novel microbial strains and new degradation pathways could be identified from polluted system using the metatranscriptomics and metaproteomics approaches (Machado et al. 2012; Junttila and Rudd 2012). Advances in genomics and the identification of quantitative trait loci (QTLs) for variety of agricultural traits offer great opportunity to identify traits that could be exploited to enhance the growth, yield and stress tolerance of crops grown in contaminated soil. Root genetics is another promising avenue to be explored for modification of root architecture, rhizoremediation of pollutants, increased water use efficiency and improved nutrient uptake, translocation and use efficiency (Meister et al. 2014; Villordon et al. 2014; Tian et al. 2014; Schmidt 2014).

Exploring nanotechnology for enhancing the degradation of pollutants (nanoremediation) in contaminated site is another promising approach to minimize the entry of toxic pollutants into the plant parts (Karn et al. 2009). Nanoparticles (NPs) like nZVI, ZnO, $\mathrm{TiO}_{2}$, carbon nanotubes, fullerenes and bimetallic nanometals can be used for soil remediation (Karn et al. 2009). NPs can immobilize soil heavy metals such as $\mathrm{Cr}(\mathrm{VI}), \mathrm{Pb}(\mathrm{II})$, As(III) and $\mathrm{Cd}$ in contaminated soils and reduce the concentration of heavy metals in leachates to values lower than the soil elution standard regulatory threshold (Mallampati et al. 2013). NPs can also mediate redox reactions that convert heavy metals such as $\mathrm{Cr}(\mathrm{VI})$ to their less toxic trivalent form $\mathrm{Cr}$ (III) in tannery waste contaminated soil. The TCLP-leachable $\mathrm{Pb}$ fraction decreased from 66 to $10 \%$ in a Pb-contaminated fire range soil following addition of NPs (Singh et al. 2012; Liu and Zhao 2013). NPs are also being used for the degradation of organic pollutants such as carbamates, chlorinated organic solvents, DDT and PCBs (Zhang 2003; El-Temsah 2013). The contaminated land remediated by nanoparticles could further be used for agricultural production. As with any emerging technology, nanotechnology too has its potential risks and benefits that need to be examined closely if it is 
to be developed and used for contaminated land remediation.

\section{Concluding remarks and future perspectives}

The continual increase in the human population coupled with scarcity of new arable lands creates the need to explore polluted lands for food production and other useful endpoints. However, there are many outstanding questions (Table 2) to be answered before the largescale exploitation of such polluted lands for agricultural production can be implemented. It would be difficult at present to measure the sustainability of crop production

Table 2 Outstanding questions regarding the sustainability of crop production from polluted lands

\begin{tabular}{|c|c|}
\hline $\begin{array}{l}\text { S1 } \\
\text { no. }\end{array}$ & Outstanding questions \\
\hline 1 & $\begin{array}{l}\text { How can inventories of the polluted lands in low income and } \\
\text { developing countries be produced to identify their potential } \\
\text { for bioeconomy? }\end{array}$ \\
\hline 2 & $\begin{array}{l}\text { What are the key sustainability challenges for the crop } \\
\text { production from multiple and heavily contaminated sites? }\end{array}$ \\
\hline 3 & $\begin{array}{l}\text { How can the general public be convinced of the safety of } \\
\text { phytoproducts? }\end{array}$ \\
\hline 4 & $\begin{array}{l}\text { What are the issues associated with the certification of } \\
\text { phytoproducts from polluted lands? }\end{array}$ \\
\hline 5 & $\begin{array}{l}\text { Can systems biology and root biology offer new solutions for } \\
\text { the sustainable utilization of polluted lands? }\end{array}$ \\
\hline 6 & $\begin{array}{l}\text { How effective will the production of phytoproducts from } \\
\text { polluted lands be under changing climate? }\end{array}$ \\
\hline
\end{tabular}

from polluted land as currently there are no valuation techniques or benchmarks for evaluating the performance of a phytoremediation-based bioeconomy. As proposed in Fig. 3, a detailed SWOT analysis is the first and foremost step toward the exploitation of such polluted lands for crop production. The recent knowledge explosion in bioremediation coupled with the concepts of sustainability and plant biodiversity is the greatest strength of such innovative practices. Moreover, the large expanses of contaminated land offer opportunities for multiple cropping for food production as well as biorefineries for bioeconomy. However, the lack of agrotechnology for cropping in polluted soils and moratoriums against the use of GM crops in many countries are major setbacks for such efforts. Crop production on multiple and heavily polluted sites represents significant challenges, particularly given the health and safety risks associated with the phytoproducts. Specific agrotechnological interventions must be optimized for cropping on polluted lands, and suitable cultivars should be selected through genetic and molecular breeding. Public perception regarding this use of contaminated land must be changed and greater awareness of the need created. There is also a need for greater stakeholder involvement. Potential conflicts of interest (if any) between different stakeholders must be properly addressed and proper monitoring and eco-toxicological risk assessments should be done at each and every stages of cropping. Importantly, the certification and marketing of phytoproducts will be a great challenge and proper regulatory mechanisms should be established to ensure the safety of such products in the marketplace.
Fig. 3 SWOT analysis for exploiting polluted lands for crop production

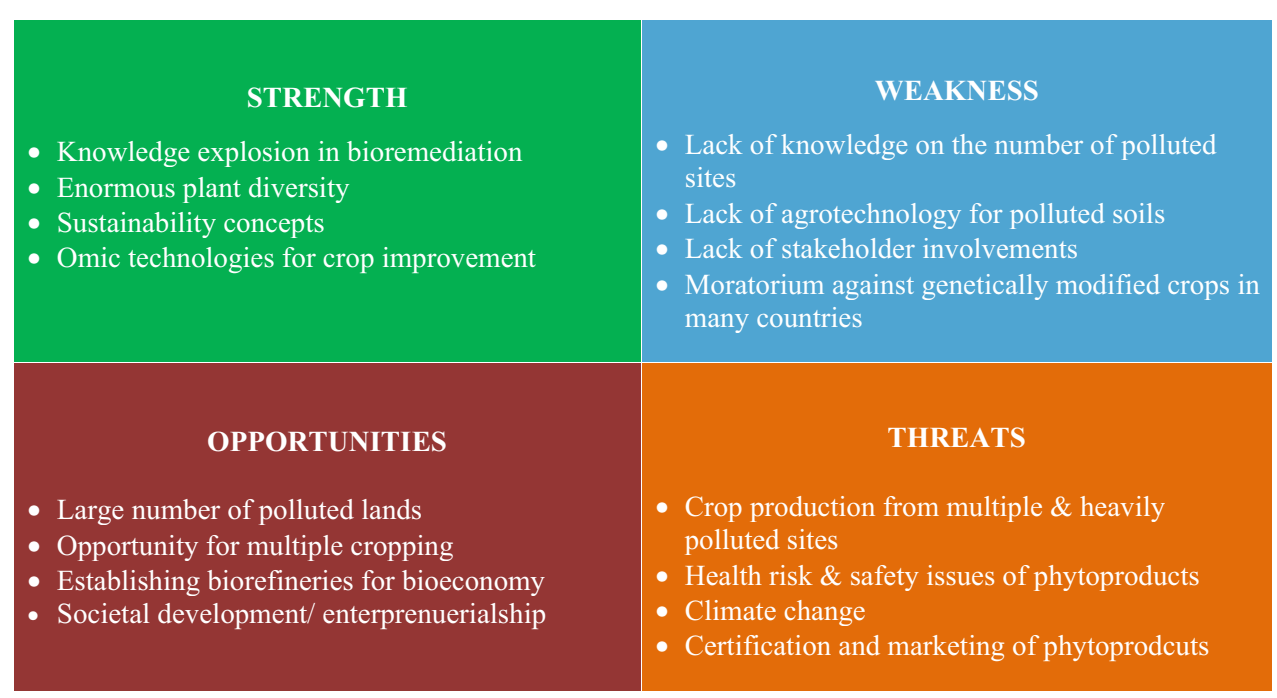


Acknowledgments We sincerely apologize to all authors those work could not be cited due to space limit. PCA is thankful to UGC, CSIR, INSA and DST for financial support.

\section{Compliance with ethical standards}

Conflict of interest The authors do not have any conflict of interest.

\section{References}

Abhilash PC, Dubey RK (2015) Root system engineering: prospects and promises. Trends Plant Sci 20:1360-1385

Abhilash PC, Jamil S, Singh N (2009) Transgenic plants for enhanced biodegradation and phytoremediation of organic xenobiotics. Biotechnol Adv 27:474-488

Abhilash PC, Powell JR, Singh HB, Singh BK (2012) Plant-microbe interactions: novel applications for exploitation in multipurpose remediation technologies. Trend Biotechnol 30:416-420

Abhilash PC, Dubey RK, Tripathi V, Srivastava P, Verma JP, Singh HB (2013a) Remediation and management of POPs-contaminated soils in a warming climate: challenges and perspectives. Environ Sci Pollut Res 20:5879-5885

Abhilash PC, Singh B, Srivastava P, Schaeffer A, Singh N (2013b) Remediation of lindane by Jatropha Curcas L: utilization of multipurpose species for rhizoremediation. Biomass Bioenergy 51:189-193

Álvareza A, Yañez ML, Benimeli CS, Amoroso MJ (2012) Maize plants (Zea mays) root exudates enhance lindane removal by native Streptomyces strains. Int Biodeterior Biodegrad 66:14-18

Anawar HM, Freitas MC, Canha N, Santa Regina I (2011) Arsenic, antimony, and other trace element contamination in a mine tailings affected area and uptake by tolerant plant species. Environ Geochem Health 33:353-362

Anderson K (2010) Globalization's effects on world agricultural trade, 1960-2050. Philos Trans R Soc Lond B Biol Sci 365:3007-3021

Banwart S (2011) Save our soils. Nature 474:151-152

Bauddh K, Singh RP (2012) Growth, tolerance efficiency and phytoremediation potential of Ricinus communis (L.) and Brassica juncea (L.) in salinity and drought affected cadmium contaminated soil. Ecotoxicol Environ Saf 85:13-22

Beilstein MA, Whanger PD, Yang GQ (1991) Chemical forms of selenium in corn and rice grown in a high selenium area of China. Biomed Environ Sci 4:392-398

Bonanno G, Cirelli GL, Toscano A, Giudice RL, Pavone P (2013) Heavy metal content in ash of energy crops growing in sewagecontaminated natural wetlands: potential applications in agriculture and forestry? Sci Total Environ 452-453:349-354

Borland AM, Griffiths H, Hartwell J, Smith JA (2009) Exploiting the potential of plants with crassulacean acid metabolism for bioenergy production on marginal lands. J Exp Bot 60:2879-2896

Cai X, Zhang X, Wang D (2011) Land availability for biofuel production. Environ Sci Technol 45:334-339

Castillo OS, Dasgupta-Schubert N, Alvarado CJ, Zaragoza EM, Villegas HJ (2011) The effect of the symbiosis between Tagetes erecta L. (marigold) and Glomus intraradices in the uptake of copper(II) and its implications for phytoremediation. Nat Biotechnol 29:156-164

Chatterjee S, Singh L (2012) A study on the waste metal remediation using floriculture at East Calcutta Wetlands, a Ramsar site in India. Environ Monit Assess 184:5139-5150
Chen BC, Lai HY, Lee DY, Juang KW (2011) Using chemical fractionation to evaluate the phytoextraction of cadmium by switchgrass from Cd-contaminated soils. Ecotoxicology 20:409-418

Dary M, Chamber-Pérez MA, Palomares AJ, Pajuelo E (2010) "In situ" phytostabilisation of heavy metal polluted soils using Lupinus luteus inoculated with metal resistant plant-growth promoting rhizobacteria. J Hazard Mater 177:323-330

de Abreu CA, Coscione AR, Pires AM, Paz-Ferreiro J (2012) Phytoremediation of a soil contaminated by heavy metals and boron using castor oil plants and organic matter amendments. J Geochem Explor 123:3-7

Delucchi M (2006) Life cycle analyses of biofuels. Draft report, Institute of Transportation Studies, University of California, Davis. http://www.its.ucdavis.edu/publications/2006/UCD-ITSRR-06-08.pdf

Doty SL, Oakley B, Xin G (2009) Diazotrophic endophytes of native black cottonwood and willow. Symbiosis 47:23-33

Dubey RK, Tripathi V, Singh N, Abhilash PC (2014) Phytoextraction of lindane by Spinacia oleracia L. Ecotoxicol Environ Saf 109:22-26

Dubey PK, Singh GS, Abhilash PC (2016) Agriculture in a changing climate. J Clean Prod. doi:10.1016/j.jclepro.2015.11.067

Dziubanek G, Piekut A, Rusin M, Baranowska R, Hajok I (2015) Contamination of food crops grown on soils with elevated heavy metals content. Ecotoxicol Environ Saf 118:183-189

Edrisi SA, Abhilash PC (2016) Exploring marginal and degraded lands for biomass and bioenergy production: an Indian scenario. Renew Sustain Energy Rev 54:1537-1551

Edrisi SA, Dubey RK, Tripathi V et al (2015) Jatropha curcas L.: a crucified plant waiting for resurgence. Renew Sustain Energy Rev 41:855-862

El-Temsah YS (2013) Effects of nano-sized zero-valent iron (nZVI) on DDT degradation in soil and its toxicity to collembola and ostracods. Chemosphere 92:131-137

Fairley P (2011) Next generation biofuels. Nat Outlook Biofuel 474:2-5

Foley JA, Ramankutty N, Brauman KA et al (2011) Solutions for a cultivated planet. Nature 478:337-342

Gao X, Lu X, Wu M, Zhang H, Pan R, Tian J, Li S, Liao H (2012) Co-inoculation with rhizobia and AMF inhibited soybean red crown rot: from field study to plant defense-related gene expression analysis. PLoS ONE 7:e33977

Garnett T, Appleby MC, Balmford A et al (2013) Sustainable intensification in agriculture: premises and policies. Science 341:33-34

Germaine KJ, Keogh E, Ryan D, Dowling DN (2009) Bacterial endophyte-mediated naphthalene phytoprotection and phytoremediation. FEMS Microbiol Lett 296:226-234

Gilbert N (2013) A hard look at GM crops. Nature 497:24-26

Godfray HCJ, Garnett T (2014) Food security and sustainable intensification. Philos Trans R Soc B 369:1471-2970

Godfray HCJ, Beddington JR, Crute IR et al (2010) Food security: the challenge of feeding 9 billion people. Science 327:812-818

González-Chávez MDC, Carrillo-González R (2013) Tolerance of Chrysantemum maximum to heavy metals: the potential for its use in the revegetation of tailings heaps. J Environ Sci 25:367-375

Guo J, Feng R, Ding Y, Wang R (2014) Applying carbon dioxide, plant growth-promoting rhizobacterium and EDTA can enhance the phytoremediation efficiency of ryegrass in a soil polluted with zinc, arsenic, cadmium and lead. J Environ Manag 141C:1-8

Houben D, Evrard L, Sonnet P (2013) Beneficial effects of biochar application to contaminated soils on the bioavailability of $\mathrm{Cd}, \mathrm{Pb}$ and $\mathrm{Zn}$ and the biomass production of rapeseed (Brassica napus L.). Biomass Bioenergy 57:196-204 
Huang H, Yu N, Wang L (2011) The phytoremediation potential of bioenergy crop Ricinus communis for DDTs and cadmium cocontaminated soil. Bioresour Technol 102:11034-11038

Hur M, Kim Y, Song HR, Kim JM, Im Choi Y, Yi H (2011) Effect of genetically modified Poplars on soil microbial communities during the phytoremediation of waste mine tailings. Appl Environ Microbiol 77:7611-7619

Ilbas AI, Yilmaz S, Akbulut M, Bogdevich O (2012) Uptake and distribution of selenium, nitrogen and sulfur in three Barley cultivars subjected to selenium applications. J Plant Nutr 35:442-452

Irshad M, Ahmad S, Pervez A, Inoue M (2014) Phytoaccumulation of heavy metals in natural plants thriving on wastewater effluent at Hattar industrial estate, Pakistan. Int $\mathrm{J}$ Phytoremediat 17:154-158

Ismail A, Riaz M, Akhtar S, Ismail T, Amir M, Zafar-ul-Hye M (2014) Heavy metals in vegetables and respective soils irrigated by canal, municipal waste and tube well water. Food Addit Contam Part B 7:213-219

Jacobsen SE, Sørensen M, Pedersen SM, Weiner J (2013) Feeding the world: genetically modified crops versus agricultural biodiversity. Agron Sustain Dev 33:651-662

Jamil S, Abhilash PC, Singh N, Sharma PN (2009) Jatropha curcas: a potential crop for phytoremediation of coal fly ash. J Hazard Mater 172:269-275

Junttila S, Rudd S (2012) Characterization of a transcriptome from a non-model organism, Cladonia rangiferina, the grey reindeer lichen, using high-throughput next generation sequencing and EST sequence data. BMC Genom 13:575

Juwarkar AA, Yadav SK, Kumar P, Singh SK (2008) Effect of biosludge and biofertilizer amendment on growth of Jatropha curcas in heavy metal contaminated soils. Environ Monit Assess 145:7-15

Karigar CS, Rao SS (2011) Role of microbial enzymes in the bioremediation of pollutants: a review. Enzyme Res. doi:10. 4061/2011/805187

Karn B, Kuiken T, Otto M (2009) Nanotechnology and in situ remediation: a review of the benefits and potential risks. Environ Health Perspect 117:1823-1831

Kashem MA et al (2010) Effect of lherzolite on chemical fractions of $\mathrm{Cd}$ and $\mathrm{Zn}$ and their uptake by plants in contaminated soil. Water Air Soil Pollut 207:241-251

Khan S, Rehman S, Khan AZ, Khan MA, Shah MT (2010) Soil and vegetables enrichment with heavy metals from geological sources in Gilgit, northern Pakistan. Ecotoxicol Environ Saf 73:1820-1827

Kline KL, Coleman MD (2010) Woody energy crops in the southeastern United States: two centuries of practitioner experience. Biomass Bioenergy 34:1655-1666

Köhler HR, Triebskorn R (2013) Wildlife ecotoxicology of pesticides: can we track effects to the population level and beyond? Science 341:759-765

Kř́ibek B, Majer V, Knésl I, Nyambe I, Mihaljevič M, Ettler V, Sracek O (2014) Concentrations of arsenic, copper, cobalt, lead and zinc in cassava (Manihot esculenta Crantz) growing on uncontaminated and contaminated soils of the Zambian Copperbelt. J Afr Earth Sci 99:713-723

Kumar BM (2013) Mining waste contaminated lands: an uphill battle for improving crop productivity. J Degrad Min Land Manag $1: 43-50$

Lal K, Minhas PS, Chaturvedi RK, Yadav RK (2008) Extraction of cadmium and tolerance of three annual cut flowers on $\mathrm{Cd}$ contaminated soils. Bioresour Technol 99:1006-1011

Lambin EF, Meyfrodt P (2011) Global land use change, economic globalization, and the looming land scarcity. Proc Natl Acad Sci USA 108:3465-3472
Ling-Zhi L et al (2011) Growth, cadmium accumulation and physiology of marigold (Tagetes erecta L.) as affected by arbuscular mycorrhizal fungi. Pedosphere 21:319-327

Liu R, Zhao D (2013) Synthesis and characterization of a new class of stabilized apatite nanoparticles and applying the particles to in situ $\mathrm{Pb}$ immobilization in a fire-range soil. Chemosphere 91:594-601

Machado A, Magalhães C, Mucha AP, Almeida CM, Bordalo AA (2012) Microbial communities within saltmarsh sediments: composition, abundance and pollution constraints. Estuar Coast Shelf Sci 99:145-152

Madejón P, Barba-Brioso C, Lepp NW, Fernández-Caliani JC (2011) Traditional agricultural practices enable sustainable remediation of highly polluted soils in Southern Spain for cultivation of food crops. J Environ Manag 92:1828-1836

Mallampati SR, Mitoma Y, Okuda T, Sakita S, Kakeda M (2013) Total immobilization of soil heavy metals with nano-Fe/Ca/CaO dispersion mixtures. Environ Chem Lett 11:119-125

Marchal G, Smith KE, Mayer P, de Jonge LW, Karlson UG (2014) Impact of soil amendments and the plant rhizosphere on PAH behaviour in soil. Environ Pollut 188:124-131

Meers E, Van Slycken S, Adriaensen K et al (2010) The use of bioenergy crops (Zea mays) for "phytoattenuation" of heavy metals on moderately contaminated soils: a field experiment. Chemosphere 78:35-41

Meister R, Rajani MS, Ruzicka D, Schachtman DP (2014) Challenges of modifying root traits in crops for agriculture. Trends Plant Sci 19:779-788

Montanarella L, Vargas R (2012) Global governance of soil resources as a necessary condition for sustainable development. Curr Opin Environ Sustain 4:559-564

Murakami M, Ae N, Ishikawa S (2007) Phytoextraction of cadmium by rice (Oryza sativa L.), soybean (Glycine max (L.) Merr.), and maize (Zea mays L.). Environ Pollut 145:96-103

Myers SS, Zanobetti A, Kloog I et al (2014) Increasing $\mathrm{CO}_{2}$ threatens human nutrition. Nature 510:139-142

Olivares AR, Carrillo-González R, González-Chávez MD, Hernández RM (2013) Potential of castor bean (Ricinus communis L.) for phytoremediation of mine tailings and oil production. J Environ Manag 114:316-323

Pavel PB, Puschenreiter M, Wenzel WW, Diacu E, Barbu CH (2014) Aided phytostabilization using Miscanthus sinensis $\times$ giganteus on heavy metal-contaminated soils. Sci Total Environ 479-480:125-131

Popp J, Pető K, Nagy J (2013) Pesticide productivity and food security. A review. Agron Sustain Dev 33:243-255

Rao MA, Scelza R, Scotti R, Gianfreda L (2010) Role of enzymes in the remediation of polluted environments. J Soil Sci Plant Nutr 10:333-353

Rastogi A, Mishra BK, Singh M, Mishra R, Shukla S (2014) Role of micronutrients on quantitative traits and prospects of its accumulation in linseed (Linum usitatissimum L.). Arch Agron Soil Sci 60:1389-1409

Ravikumar M, Sarita P, Naga Raju GJ, Bhuloka Reddy S (2013) Trace element accumulation in the leaves of Azadirachta indica and Pongamia glabra collected from different environmental sites. J Environ Res Dev 7:1209-1215

Rayman MP (2008) Food-chain selenium and human health: emphasis on intake. Br J Nutr 100:254-268

Rayman MP, Infante HG, Sargent M (2008) Food-chain selenium and human health: spotlight on speciation. Br J Nutr 100:238-253

Rockström J, Steffen W, Noone K et al (2009) A safe operating space for humanity. Nature 461:472-475

Ronald P (2011) Plant genetics, sustainable agriculture and global food security. Genetics 188:111-120 
Ruttens A, Boulet J, Weyens N (2011) Short rotation coppice culture of willows and poplars as energy crops on metal contaminated agricultural soils. Int J Phytoremediat 13:94-207

Schmidt W (2014) Root systems biology. Front Plant Sci 5:1-2

Segura A, Ramos JL (2013) Plant-bacteria interactions in the removal of pollutants. Curr Opin Biotechnol 24:467-473

Singh R, Misra V, Singh RP (2012) Removal of Cr(VI) by nanoscale zero-valent iron (nZVI) from soil contaminated with tannery wastes. Bull Environ Contam Toxicol 88:210-214

Sipos G, Solti A, Czech V, Vashegyi I, Tóth B, Cseh E, Fodor F (2013) Heavy metal accumulation and tolerance of energy grass (Elymus elongatus subsp. ponticus cv. Szarvasi-1) grown in hydroponic culture. Plant Physiol Biochem 68:96-103

Solís-Domínguez FA, Valentín-Vargas A, Chorover J, Maier RM (2011) Effect of arbuscular mycorrhizal fungi on plant biomass and the rhizosphere microbial community structure of mesquite grown in acidic lead/zinc mine tailings. Sci Total Environ 409:1009-1016

Stadlober M, Sager M, Irgolic KJ (2001) Effects of selenate supplemented fertilization on the selenium level of cerealsidentification and quantification of selenium compounds by HPLC-ICP-MS. Food Chem 73:357-366

Stasinos S, Zabetakis I (2013) The uptake of nickel and chromium from irrigation water by potatoes, carrots and onions. Ecotoxicol Environ Saf 91:122-128

Tang Y, Xie JS, Geng S (2010) Marginal land-based biomass energy production in China. J Integr Plant Biol 52:112-121

Técher D, Laval-Gilly P, Henry S et al (2011) Contribution of Miscanthus $x$ giganteus root exudates to the biostimulation of PAH degradation: an in vitro study. Sci Total Environ 409:4489-4495

Tian YL, Zhang HY, Guo W, Wei XF (2014) Morphological responses, biomass yield and bioenergy potential of sweet sorghum cultivated in cadmium- contaminated soil for biofuel. Int J Green Energy 12:577-584

Tripathi P, Singh PC, Mishra A, Chauhan PS, Dwivedi S, Bais RT, Tripathi RD (2013) Trichoderma: a potential bioremediator for environmental cleanup. Clean Technol Environ Policy 15:541-550

Tripathi V, Dubey RK, Edrisi SA, Narain K, Singh HB, Singh N, Abhilash PC (2014a) Towards the ecological profiling of a pesticide contaminated soil site for remediation and management. Ecol Eng 71:318-325

Tripathi V, Dubey RK, Singh N, Singh HB, Abhilash PC (2014b) Is Vigna radiata is suitable for cropping in lindane contaminated soil? Ecol Eng 73:219-223

Tripathi V, Fraceto LF, Abhilash PC (2015a) Sustainable clean-up technologies for soils contaminated with multiple pollutants: plant-microbe-pollutant and climate nexus. Ecol Eng 82:330-335

Tripathi V, Abhilash PC, Singh HB, Patra DD, Singh N (2015b) Effect of temperature variation on lindane dissipation and microbial activity in soils. Ecol Eng 79:54-59

Vamerali T, Bandiera M, Lucchini P, Dickinson NM, Mosca G (2014) Long-term phytomanagement of metal-contaminated land with field crops: integrated remediation and biofortification. Eur $\mathrm{J}$ Agron 53:56-66
Van Slycken S, Witters N, Meers E et al (2013) Safe use of metalcontaminated agricultural land by cultivation of energy maize (Zea mays). Environ Pollut 178:375-380

Vandenhove H, Hees MV (2005) Fibre crops as alternative land use for radioactively contaminated arable land. J Environ Radioact 81:131-141

Villordon AQ, Ginzberg I, Firon N (2014) Root architecture and root and tuber crop productivity. Trends Plant Sci 19:419-425

Vishnoi SR, Srivastava PN (2008) Phytoremediation-green for environmental clean. In: The 12th world lake conference, pp 1016-1021

Wang XF, Zhou QX (2005) Ecotoxicological effects of cadmium on three ornamental plants. Chemosphere 60:16-21

Wang GD, Li QJ, Luo B, Chen XY (2004) Ex planta phytoremediation of trichlorophenol and phenolic allelochemicals via an engineered secretory laccase. Nat Biotechnol 22:893-897

Warren GP, Alloway BJ, Lepp NW, Singh B, Bochereau FJ, Penny C (2003) Field trials to assess the uptake of arsenic by vegetables from contaminated soils and soil remediation with iron oxides. Sci Total Environ 311:19-33

Weyens N, van der Lelie D, Taghavi S, Newman L, Vangronsveld J (2009) Exploiting plant microbe partnerships to improve biomass production and remediation. Trend Biotechnol 27:591-598

Weyens N, Beckers B, Schellingen K (2013) The potential of the Niresistant TCE-degrading Pseudomonas putida W619-TCE to reduce phytotoxicity and improve phytoremediation efficiency of poplar cuttings on a Ni-TCE co-contamination. Int $\mathrm{J}$ Phytoremediat 17:40-48

Williams PN, Lombi E, Sun GX (2009) Selenium characterization in the global rice supply chain. Environ Sci Technol 43:6024-6030

Willscher S, Mirgorodsky D, Jablonski L (2013) Field scale phytoremediation experiments on a heavy metal and uranium contaminated site, and further utilization of the plant residues. Hydrometallurgy 131-132:46-53

Ye-Tao TA, Teng-Hao-Bo DE, Qi-Hang WU (2012) Designing cropping systems for metal-contaminated sites: a review. Pedosphere 22:470-488

Yu L, Zhu J, Huang Q, Su D, Jiang R, Li H (2014) Application of a rotation system to oilseed rape and rice fields in Cd-contaminated agricultural land to ensure food safety. Ecotoxicol Environ Saf 108:287-293

Zaidi S, Usmani S, Singh BR, Musarrat J (2006) Significance of Bacillus subtilis strain SJ-101 as a bioinoculant for concurrent plant growth promotion and nickel accumulation in Brassica juncea. Chemosphere 64:991-997

Zhang WX (2003) Nanoscale iron particles for environmental remediation: an overview. J Nanoparticle Res 5:323-332

Zhao FJ, McGrath SP (2009) Biofortification and phytoremediation. Curr Opin Plant Biol 12:373-380

Zhu YG, Pilon-Smits EA, Zhao FJ, Williams PN, Meharg AA (2009) Selenium in higher plants: understanding mechanisms for biofortification and phytoremediation. Trend Plant Sci $14: 436-442$

Zhuang P, Shu W, Li Z, Liao B, Li J, Shao J (2009) Removal of metals by sorghum plants from contaminated land. J Environ Sci 21:1432-1437 